\title{
Hepatic Venous Pressure Gradient Response in Non-Selective Beta-Blocker Treatment-Is It Worth Measuring?
}

\author{
Mattias Mandorfer ${ }^{1,2}$ • Virginia Hernández-Gea ${ }^{2,3,4}$ • Thomas Reiberger ${ }^{1}$ Juan Carlos García-Pagán ${ }^{2,3,4}$
}

Published online: 2 May 2019

(C) The Author(s) 2019

\begin{abstract}
Purpose of Review To review the evidence supporting the assessment of hepatic venous pressure gradient (HVPG) response to non-selective beta-blockers (NSBB).

Recent Findings HVPG response to NSBB reduces the risks of variceal bleeding, hepatic decompensation due to ascites and its complications, and, finally, mortality. In hemodynamic non-responders to NSBB, their effectiveness is suboptimal, although there is increasing evidence for non-hemodynamic effects. Carvedilol may be a good treatment option for patients with nonresponse to conventional NSBB, as it is more potent in decreasing HVPG. Furthermore, hemodynamic non-responders may also benefit from (the addition of) other HVPG-lowering drugs that are in clinical development, and, depending on the setting, complimentary or alternative treatment strategies.

Summary Clinical benefits of HVPG response have been established throughout a broad spectrum of advanced chronic liver disease (ACLD) severity, ranging from compensated patients without varices but with clinically significant portal hypertension $(\mathrm{CSPH})$ to subjects with a history of bleeding and/or non-bleeding hepatic decompensation. HVPG-guided NSBB therapy facilitates personalized medicine in patients with ACLD and portal hypertension. Since the clinical use of HVPG measurement is limited by its invasiveness and its availability is mostly restricted to academic centers, the development of non-invasive surrogates of HVPG response is of high clinical relevance.
\end{abstract}

Keywords Cirrhosis $\cdot$ Portal hypertension $\cdot \mathrm{HVPG} \cdot \mathrm{NSBB} \cdot$ Variceal bleeding $\cdot$ Ascites

\section{Introduction}

Portal pressure, assessed by hepatic venous pressure gradient (HVPG) measurement, is a key factor promoting the development of liver-related complications and mortality in patients

This article is part of the Topical Collection on Portal Hypertension

Mattias Mandorfer

mattias.mandorfer@meduniwien.ac.at

1 Vienna Hepatic Hemodynamic Laboratory, Division of Gastroenterology and Hepatology, Department of Internal Medicine III, Medical University of Vienna, Waehringer Guertel 18-20, 1090 Vienna, Austria

2 Barcelona Hepatic Hemodynamic Laboratory, Liver Unit, Hospital Clínic, Barcelona, Spain

3 Institut d'Investigacions Biomèdiques August Pi i Sunyer (IDIBAPS), Barcelona, Spain

4 Centro de Investigación Biomédica en Red de Enfermedades Hepáticas y Digestivas (CIBERehd), Barcelona, Spain with advanced chronic liver disease (ACLD; i.e., a novel term for the spectrum of advanced liver fibrosis/cirrhosis) [1,2].

Since their introduction in the nineteen-eighties, nonselective beta-blockers (NSBB) are a cornerstone in the treatment of portal hypertension. During the last years, our understanding of potential benefits of early initiation of NSBB treatment as well as potential detrimental effects in patients with advanced disease has continuously evolved $[3 \bullet \bullet, 4 \bullet, 5 \bullet \bullet]$.

In patients with medium to large varices who have not bled (i.e., patients with high-risk varices, and, thus, a clear indication for primary prophylaxis of acute variceal bleeding $[\mathrm{AVB}][6,7])$, NSBB treatment decreased the 2-year risk of variceal hemorrhage from 30 to $14 \%$ (absolute risk reduction [ARD]: $-16 \%$ [ $-24 \%$ to $-8 \%]$; number needed to treat [NNT]: 6) [8]. Moreover, NSBB reduced the risk of recurrent variceal bleeding (secondary prophylaxis) from $63 \%$ to $42 \%$ (ARD: $-21 \%$ [ $-30 \%$ to $-13 \%$ ]; NNT: 5 ). Since the NNT ranges from 5 to 6 , many patients have to be treated with NSBB to prevent a single variceal bleeding. A crucial factor limiting the efficacy of NSBB is the high 
intersubjective variability in the reduction of portal pressure $[3 \cdot \bullet]$, underlining the need for reliable methods to assess the expectable benefits in the individual patient, i.e., the assessment of HVPG response.

This review summarizes (a) the current evidence for assessing HVPG response to NSBB therapy for prognostication and guiding treatment decisions in different clinical settings/stages of ACLD, (b) the clinical and procedural requirements for obtaining optimal results, and (c) the potential non-invasive markers for HVPG response.

\section{Definition and Impact of HVPG Response}

\section{"Chronic" HVPG Response to NSBB}

According to the initial studies in primary [9] and secondary prophylaxis [10], patients are protected from AVB if HVPG decreases to a value of $\leq 12 \mathrm{mmHg}$ during NSBB treatment (primary prophylaxis: $0 \%$ vs. $29 \%$ at 52 months; secondary prophylaxis, NSBB monotherapy: $0 \%$ vs. $41 \%$ with a mean follow-up of 28 months). Similarly, a HVPG reduction by $\geq$ $20 \%$, which is achieved much more commonly than a decrease to $\leq 12 \mathrm{mmHg}$, substantially reduced the risk of bleeding (secondary prophylaxis, NSBB monotherapy: $4 \%$ vs. $28 \%, 9 \%$ vs. $39 \%$, and $9 \%$ vs. $66 \%$ at 1,2 , and 3 years, respectively) [10]. The combination of these criteria has been used to define "chronic" HVPG response to conventional NSBB (propranolol and nadolol) or carvedilol treatment as well as investigational drugs for portal hypertension of varying modes of action. This includes several classes of repurposed drugs (most prominently nitrates isosorbide mononitrate (ISMN), alpha 1-antagonists [prazosin], and statins [11-13]), but also novel agents specifically developed for the treatment of portal hypertension [14•]. Importantly, for primary prophylaxis, the Baveno VI faculty recently reduced the threshold for achieving HVPG response to a decrease $\geq$ $10 \%$ (or to a value of $\leq 12 \mathrm{mmHg}$ ), while the definition of HVPG response in the secondary prophylaxis remained unchanged ( $\geq 20 \%$ or to a value of $\leq 12 \mathrm{mmHg}$ ) [6].

A summary of studies evaluating the prognostic impact of HVPG response is shown in Table 1. Besides AVB/bleeding, "chronic" HVPG response to conventional $\mathrm{NSBB} \pm$ other HVPG-lowering drugs (ISMN or prazosin) has been shown to decrease the risks of occurrence/worsening of ascites [16, $17,23]$ as well as its complications [16, 17, 23], such as spontaneous bacterial peritonitis (SBP) $[16,17]$. In addition, some studies even reported (trends towards) a decrease in hepatic encephalopathy (HE) [16, 17], a decompensating event which is less closely linked to portal hypertension. However, this association was not observed in another study [19]. The respective effect sizes are reported in Table 1. Moreover, "chronic" HVPG response has been linked to a decreased need for liver transplantation [17] and has repeatedly been found to be independently associated with improved survival $[9,10,15-17]$. Of note, the relevance of competing risks, such as liver transplantation or death, in prognostic studies investigating bleeding and non-bleeding hepatic decompensation is increasingly acknowledged [24•]. However, no competing risk analyses were performed in the studies on the predictive value of HVPG response, which may have compromised the accuracy of risk estimates.

Besides establishing its value as an independent prognostic marker, other important conclusions can be drawn from studies on "chronic" HVPG response. First, hemodynamic response can be maintained over long periods of time, as indicated by studies performing repeated HVPG measurements $[18,22,25]$. However, with increasing time between the HVPG measurements, the course of the underlying liver disease becomes more and more important as a determinant of HVPG response (also, see the "Clinical and Procedural Requirements for HVPG Response-Guided Therapy" section). This conclusion is supported by studies observing higher rates of (maintained) HVPG response in patients with alcoholic etiology [9], particularly in those who continue to abstain from alcohol $[17,22]$. Accordingly, to assess the unbiased effect of a pharmaceutical intervention, the period between the HVPG assessments should be minimized. However, both dynamics of the underlying etiology as well as drug effects modify the risk for (further) hepatic decompensation and mortality. Thus, from a prognostic point of view, "chronic" HVPG response may even yield additional information. Nevertheless, the situation is different if HVPG response is used to guide individualized treatment decisions, an approach termed HVPG response-guided therapy.

\section{"Acute" HVPG Response to NSBB}

In addition to the above-mentioned limitations, the assessment of "chronic" HVPG response to NSBB is resource-intensive due to the need for two separate HVPG measurements. Moreover, in studies investigating HVPG-guided therapy for secondary prophylaxis, a relevant proportion of patients $(5 \%$ [26], 9\% [27], and 12\% [28]) had already bled before the "chronic" HVPG response was assessed (i.e., within the NSBB titration period and prior to the second HVPG measurement). Thus, the value of measuring the "acute" HVPG response to i.v. propranolol has been evaluated. The first two studies on "acute" HVPG response comprised patients in primary prophylaxis [20] or a combination of patients in primary and secondary prophylaxis [21]. A HVPG reduction $\geq 10 \%$ [20] to $\geq 12 \%$ [21] has been shown to be sufficient in the "acute" HVPG response setting. In both studies, an adequate HVPG response to i.v. propranolol $(0.15 \mathrm{mg} / \mathrm{kg}[20,21]$, followed by $0.2 \mathrm{mg} / \mathrm{h}$ in the first study [20]) was protective of AVB ( $4 \%$ vs. $46 \%$ and $16 \%$ vs. $40 \%$ at 2 years) in patients 
Table 1 Studies evaluating the prognostic impact of hepatic venous pressure gradient (HVPG) response to non-selective beta-blockers (NSBB)

\begin{tabular}{|c|c|c|c|c|}
\hline Study & $\begin{array}{l}\text { Number of } \\
\text { patients }\end{array}$ & Interventions & $\begin{array}{l}\text { Setting/patient } \\
\text { characteristics }\end{array}$ & Remarks/key findings \\
\hline $\begin{array}{l}\text { Groszmann et al. } \\
\text { Gastroenterology } \\
\quad 1990[9]\end{array}$ & $\begin{array}{l}n=102 \\
n=84 \text { with } \\
\quad \text { informa- } \\
\text { tion on } \\
\quad \text { HVPG } \\
\text { response }\end{array}$ & $\begin{array}{l}\text { Propranolol (titrated according to } \mathrm{HVPG} / \mathrm{HR} \text {, } \\
n=51) \text { vs. placebo }(n=51) \text {; "chronic" } \\
\text { HVPG response }\end{array}$ & $\begin{array}{l}\text { Primary prophylaxis (small: } \\
28 \% \text {, medium: } 17 \% \text {, large: } \\
5 \% \text { varices) } \\
\text { HVPG } \geq 12 \mathrm{mmHg}\end{array}$ & $\begin{array}{l}\text { Patients with alcoholic cirrhosis more likely } \\
\text { to decrease to } \leq 12 \mathrm{mmHg} \\
\text { AVB: HVPG } \leq 12 \mathrm{mmHg}: 0 \% \text { vs. } \\
\geq 12 \mathrm{mmHg}: 29 \% \text { at } 52 \text { months } \\
\text { Mortality: decreased }\end{array}$ \\
\hline $\begin{array}{l}\text { Feu et al. } \\
\text { Lancet } 1995[10]\end{array}$ & $\begin{array}{l}n=83 \\
n=69 \text { with } \\
\text { informa- } \\
\text { tion on } \\
\text { HVPG } \\
\text { response }\end{array}$ & $\begin{array}{l}\text { Propranolol (titrated according to HR/SAP); } \\
\text { "chronic" HVPG response ( } 3 \text { months) }\end{array}$ & Secondary prophylaxis & $\begin{array}{l}\text { Bleeding: } 0 \% \text { if } \mathrm{HVPG} \leq 12 \mathrm{mmHg} \text { (highly } \\
\text { sensitive), but low specificity } \\
\text { HVPG decrease } \geq 20 \%: 4 \% / 9 \% / 9 \% \text { vs. } \\
\quad<20 \%: 28 \% / 39 \% / 66 \% \text { at } 1 / 2 / 3 \text { years } \\
\text { Mortality: trend towards decrease }\end{array}$ \\
\hline $\begin{array}{l}\text { Merkel et al. } \\
\text { Hepatology } 2000 \\
\quad[15]\end{array}$ & $n=49$ & $\begin{array}{l}\text { Nadolol (titrated according to HR) } \pm \text { ISMN; } \\
\text { "chronic" HVPG response }\end{array}$ & $\begin{array}{l}\text { Primary prophylaxis (all } \\
\text { high-risk varices) } \\
\mathrm{HVPG} \geq 12 \mathrm{mmHg} \\
\text { Definition of } \mathrm{HVPG} \text { response: } \\
\quad \leq 12 \mathrm{mmHg} / \geq 20 \%\end{array}$ & $\begin{array}{l}A V B: \text { HVPG response: } 7 \% \text { vs. non-response: } \\
41 \% \text { at } 3 \text { years } \\
\text { Mortality: decreased if } \mathrm{HVPG} \leq 12 \mathrm{mmHg}\end{array}$ \\
\hline $\begin{array}{l}\text { Abraldes et al. } \\
\text { Hepatology } 2003 \\
\quad[16]\end{array}$ & $\begin{array}{l}n=105 \\
n=73 \text { with } \\
\text { informa- } \\
\text { tion on } \\
\text { HVPG } \\
\text { response }\end{array}$ & $\begin{array}{l}\text { Nadolol (titrated according to HR and } \\
\text { SAP) } \pm \text { ISMN; "chronic" HVPG response } \\
\text { (median: } 111 \text { days) }\end{array}$ & $\begin{array}{l}\text { Secondary prophylaxis; } \\
\text { Definition of HVPG response: } \\
\quad \leq 12 \mathrm{mmHg} / \geq 20 \%\end{array}$ & $\begin{array}{l}\text { Follow-up of up to } 8 \text { years; } \\
\text { AVB: HVPG response: } 28 \% \text { vs. } \\
\text { non-response: } 57 \% \text { at } 8 \text { years } \\
\text { (independently predictive); } \\
\text { Ascites: HVPG response: } 30 \% \text { vs. } \\
\text { non-response: } 58 \% \text { at } 8 \text { years } \\
\text { (independently predictive); } \\
\text { SBP/spontaneous bacteremia: HVPG } \\
\text { response: } 6 \% \text { vs. non-response: } 42 \% \text { at } \\
8 \text { years (independently predictive); } \\
\text { HE: HVPG response: } 16 \% \text { vs. } \\
\text { non-response: } 42 \% \text { at } 8 \text { years; } \\
\text { Mortality: HVPG response: } 5 \% \text { vs. } \\
\text { non-response: } 42 \% \text { at } 8 \text { years } \\
\text { (independently predictive) }\end{array}$ \\
\hline $\begin{array}{l}\text { Villanueva et al. } \\
\text { J Hepatol } 2004 \\
\quad[17]\end{array}$ & $n=132$ & $\begin{array}{l}\text { Nadolol (titrated according to HR) + ISMN; 1st } \\
\text { "chronic" HVPG response assessment } \\
\text { (median: } 58 \text { days); } 2 \text { nd "chronic" HVPG } \\
\text { response assessment (median: } 16 \text { months) }\end{array}$ & $\begin{array}{l}\text { Secondary prophylaxis; } \\
\text { Definition of } \mathrm{HVPG} \text { response: } \\
\leq 12 \mathrm{mmHg} / \geq 20 \%\end{array}$ & $\begin{array}{l}\text { Alcohol abstinence more common in } \\
\text { hemodynamic responders; } \\
\text { Bleeding: } 4 \% \text { vs. } 32 \% \text { at } 2 \text { years; } \\
\text { Ascites: } 27 \% \text { vs. } 56 \% \text { (de novo: } 3 \% \text { vs. } \\
\text { 10\%); } \\
\text { SBP: } 3 \% \text { vs. } 12 \% \text {; } \\
\text { HRS: } 3 \% \text { vs. } 12 \% \text {; } \\
\text { HE: } 11 \% \text { vs. } 31 \% \text { (de novo: } 5 \% \text { vs. } 16 \% \text { ); } \\
\text { Liver transplantation: } 2 \% \text { vs. } 15 \% \text {; } \\
\text { Mortality: } 17 \% \text { vs. } 32 \% \text { (independently } \\
\text { predictive); } \\
\text { Maintenance of hemodynamic response: } \\
\quad \text { Initial HVPG response maintained in } \\
\text { 81\% at 2nd response assessment }\end{array}$ \\
\hline $\begin{array}{l}\text { Groszmann et al. } \\
\text { New Engl J Med } \\
\quad 2005[18]\end{array}$ & $\begin{array}{c}n=213 \\
\text { random- } \\
\text { ized to } \\
\text { timolol vs. } \\
\text { placebo; } \\
n=154 \text { with } \\
\text { informa- } \\
\text { tion on } \\
\quad \text { HVPG } \\
\text { response }\end{array}$ & $\begin{array}{l}\text { Timolol (titrated according to HR); "chronic" } \\
\text { HVPG response (1 year) }\end{array}$ & $\begin{array}{l}\text { Pre-primary prophylaxis (no } \\
\text { varices, CSPH: } 58 \% \text { ); } \\
\text { HVPG } \geq 6 \mathrm{mmHg}\end{array}$ & $\begin{array}{l}\text { Development of varices or AVB: decreased if } \\
\text { HVPG decrease } \geq 10 \%\end{array}$ \\
\hline $\begin{array}{l}\text { Turnes et al. } \\
\text { Am J } \\
\text { Gastroenterol } \\
2006[19]\end{array}$ & $n=71$ & $\begin{array}{l}\text { Propranolol (titrated according to HR) + ISMN; } \\
\text { "chronic" HVPG response (median: } \\
4 \text { months) }\end{array}$ & $\begin{array}{l}\text { Primary prophylaxis (small: } \\
4 \%, \text { medium: } 42 \% \text {, large: } \\
37 \% \text { varices); } \\
\text { HVPG } \geq 12 \mathrm{mmHg} ; \\
\text { Definition of } \mathrm{HVPG} \text { response: } \\
\leq 12 \mathrm{mmHg} / \geq 20 \%\end{array}$ & $\begin{array}{l}\text { Follow-up of up to } 8 \text { years; } \\
\text { AVB: HVPG response: } 10 \% \text { vs. } \\
\quad \text { non-response: } 55 \% \text { at } 8 \text { years; } \\
\text { Ascites: comparable; } \\
\text { SBP/spontaneous bacteremia: comparable; } \\
\text { HE: comparable; } \\
\text { Liver transplantation: comparable; } \\
\text { Mortality: comparable }\end{array}$ \\
\hline $\begin{array}{l}\text { Villanueva et al. } \\
\text { Gastroenterology } \\
2009[20]\end{array}$ & $n=105$ & $\begin{array}{l}\text { "Acute" HVPG response to i.v. propranolol } \\
(0.15 \mathrm{mg} / \mathrm{kg} \text { followed by } 0.2 \mathrm{mg} / \mathrm{h}) ; \\
\text { Nadolol (titrated according to } \mathrm{HR})\end{array}$ & $\begin{array}{l}\text { Primary prophylaxis (all } \\
\text { high-risk varices); } \\
\text { HVPG } \geq 12 \mathrm{mmHg} ; \\
\text { Definition of } \mathrm{HVPG} \text { response: } \\
\quad \leq 12 \mathrm{mmHg} / \geq 20 \%\end{array}$ & $\begin{array}{l}\text { AVB: HVPG response: } 4 \% \text { vs. non-response: } \\
46 \% \text { at } 2 \text { years (independently } \\
\text { predictive); } \\
\text { Ascites: decreased; } \\
\text { Mortality: trend towards decrease, moderate } \\
\text { correlation between "acute" and } \\
\text { "chronic" HVPG response }\end{array}$ \\
\hline $\begin{array}{l}\text { La Mura et al. } \\
\text { J Hepatol } 2009 \\
\quad[21]\end{array}$ & $n=166$ & $\begin{array}{l}\text { "Acute" HVPG response to i.v. propranolol } \\
(0.15 \mathrm{mg} / \mathrm{kg}) \text {; } \\
\text { Propranolol or nadolol (titrated according to } \\
\text { HR/SAP) }\end{array}$ & $\begin{array}{l}\text { Primary }(n=78 ; \text { small: } 22 \% \text {; } \\
\text { large: } 78 \% \text { varices, red } \\
\text { wale marks: } 29 \%) \text { and } \\
\text { secondary prophylaxis } \\
\quad(n=88) ; \\
\text { HVPG } \geq 12 \text { mmHg; } \\
\text { Definition of HVPG response: } \\
\quad \geq 12 \%\end{array}$ & $\begin{array}{l}A V B \text { : HVPG response: } 7 \% / 16 \% \text { vs. } \\
\text { non-response: } 21 \% / 40 \% \text { at } 1 / 2 \text { years } \\
\text { (independently predictive); } \\
\text { AVB (primary prophylaxis): trend towards } \\
\text { decrease; } \\
\text { AVB (secondary prophylaxis): decreased } \\
\quad \text { (independently predictive); } \\
\text { Mortality: HVPG response: } 5 \% / 5 \% \text { vs. } \\
\text { non-response: } 13 \% / 35 \% \text { at } 1 / 2 \text { years } \\
\text { (independently predictive); }\end{array}$ \\
\hline
\end{tabular}


Table 1 (continued)

\begin{tabular}{|c|c|c|c|c|}
\hline Study & $\begin{array}{l}\text { Number of } \\
\text { patients }\end{array}$ & Interventions & $\begin{array}{l}\text { Setting/patient } \\
\text { characteristics }\end{array}$ & Remarks/key findings \\
\hline $\begin{array}{l}\text { Hernández-Gea } \\
\text { et al. } \\
\text { Am J } \\
\text { Gastroenterol } \\
2013 \text { [23] }\end{array}$ & $\begin{array}{l}n=103 \\
n=90 \text { with } \\
\text { informa- } \\
\text { tion on } \\
\text { HVPG } \\
\text { response }\end{array}$ & $\begin{array}{l}\text { "Acute" HVPG response to i.v. propranolol } \\
\text { ( } 0.15 \mathrm{mg} / \mathrm{kg}) ; \\
\text { Nadolol (titrated according to HR); } \\
\text { "Chronic" HVPG response ( } 1-3 \text { months) }\end{array}$ & $\begin{array}{l}\text { Primary prophylaxis (all large } \\
\text { varices); } \\
\text { HVPG } \geq 12 \mathrm{mmHg} \text {; } \\
\text { Definition of HVPG response: } \\
\quad \geq 10 \%\end{array}$ & $\begin{array}{l}\text { Mortality (primary prophylaxis): trend } \\
\text { towards decrease; } \\
\text { Mortality (secondary prophylaxis): } \\
\text { decreased (independently predictive); } \\
\text { Considerable discordance between "acute" } \\
\text { and "chronic" HVPG response status } \\
\text { Bleeding: increased, comparable after } \\
\text { excluding patients undergoing TIPS; } \\
\text { Non-bleeding hepatic decompensation: } \\
\text { trend towards decrease; } \\
\text { Mortality: decreased (independently } \\
\text { predictive); } \\
\text { Maintenance of hemodynamic response: } \\
\text { 65\%, abstinent: } 100 \% \text { vs. non-abstinent: } \\
\text { 36\%, associated with lower bleeding and } \\
\text { mortality } \\
\text { Bleeding: "chronic" HVPG response: } 5 \% \\
\text { vs. non-response: } 17 \% \text { at } 2 \text { years } \\
\text { (independently predictive); } \\
\text { AVB: "chronic" HVPG response: } 5 \% \text { vs. } \\
\text { non-response: } 14 \% \text { at } 2 \text { years; } \\
\text { Ascites: "acute" assessment: AUROC of } \\
\text { 0.74, predictive performance inferior to } \\
\text { "chronic" assessment, "chronic" } \\
\text { assessment: AUROC of 0.84, optimal } \\
\text { cut-off HVPG decrease } \geq 10 \% \text { (i.e., } \\
\text { definition of HVPG response); "chronic" } \\
\text { HVPG response: } 27 \% \text { vs. non-response: } \\
\text { 89\% (independently predictive); "acute" } \\
\text { HVPG response: } 17 \% \text { vs. non-response: } \\
\text { 49\% at } 2 \text { years; } \\
\text { Refractory ascites: decreased if "chronic" } \\
\text { hemodynamic response; "acute" HVPG } \\
\text { response: } 5 \% \text { vs. non-response: } 18 \% \text { at } \\
2 \text { years; } \\
\text { SBP: comparable; } \\
\text { HRS: decreased if "chronic" HVPG } \\
\text { response; trend towards decrease if } \\
\text { "acute" HVPG response; } \\
\text { HE: trend towards decrease if "chronic' } \\
\text { hemodynamic response; } \\
\text { Mortality: decreased if "chronic" HVPG } \\
\text { response }\end{array}$ \\
\hline
\end{tabular}

$\mathrm{HR}$, heart rate; AVB, acute variceal bleeding; SAP, systolic arterial pressure; ISMN, isosorbide mononitrate; SBP, spontaneous bacterial peritonitis; HE, hepatic encephalopathy; TIPS, transjugular intrahepatic portosystemic shunt; AUROC, area under the receiver operating characteristic curve

receiving nadolol during follow-up. Moreover, Villanueva et al. [20] observed a reduced incidence of ascites or worsening of ascites in patients with "acute" hemodynamic response. The authors also observed trends towards a decrease in mortality, which attained statistical significance in the subgroup of patients with a previous bleeding episode [21]. Interestingly, there was only a moderate correlation between "acute" and "chronic" relative changes in HVPG [20], which resulted in a considerable proportion of patients with discordant HVPG response results [21]. A third study on the prognostic value of "acute" HVPG response specifically addressed the question whether HVPG response can predict the first development of ascites [23], which is the most common first decompensating event [24•]. In addition to preventing de novo ascites, "acute" HVPG response was also associated with a decreased incidence of refractory ascites, SBP, and hepatorenal syndrome (HRS). However, the predictive value of "chronic" HVPG response was higher (area under the receiver operating characteristic curve [AUROC]: 0.84), as compared to "acute"
HVPG response (AUROC: 0.74). This may be explained by the incremental prognostic information obtained by the longitudinal assessment of HVPG, since longitudinal assessments also allow to integrate prognostic information related to the evolution of the underlying etiology - most prominently, alcohol abstinence.

\section{Stage-Dependent Impact of HVPG Response to NSBB}

To date, HVPG response is the only well-established surrogate for the effectiveness of NSBB treatment. It is defined by a decrease in HVPG that will translate into clinically meaningful benefits [1, 2]. HVPG response confers important prognostic information across several stages of ACLD [24•], which are as follows: stage 2 (compensated, with varices), stage 3 (decompensated, bleeding alone), stage 4 (decompensated, ascites with or without bleeding), and stage 5 (second decompensating event, i.e., further hepatic decompensation). However, HVPG response may also be beneficial in earlier 
stages. In their seminal study, Groszmann et al. [18] randomly assigned 213 patients with portal hypertension (HVPG $\geq$ $6 \mathrm{mmHg}$ ) but without varices (pre-primary prophylaxis) to timolol or placebo. Patients who achieved a HVPG decrease $\geq$ $10 \%$ at 1 year showed a lower incidence of the composite endpoint (development of varices or AVB). This beneficial effect might be mainly attributed to the $58 \%$ of patients who had CSPH at inclusion, since patients without CSPH are at low risk to develop the composite endpoint of varices or AVB, which was also one of the main findings of this study. Moreover, patients with CSPH, as compared to patients without CSPH, show substantially more pronounced NSBBinduced decreases in HVPG [29]. Accordingly, there is also limited evidence for the prognostic value of HVPG response in early-stage ACLD (i.e., stage 1 (compensated, without varices) $[24 \bullet])$, if CSPH is present.

\section{Clinical and Procedural Requirements for HVPG Response-Guided Therapy}

To begin with, a high degree of standardization is essential to accurately assess changes in HVPG to pharmacological interventions, such as NSBB, since even small changes (i.e., $1 \mathrm{mmHg}$ ) in HVPG may discriminate between hemodynamic responders and non-responders. Details regarding the procedure are reviewed elsewhere [30]. Moreover, there is a comprehensive protocol for this technique published in a visual format $[31 \bullet \cdot$. The correct positioning of the balloon catheter, which should be preferred over straight catheters $[32,33]$, is one of the most critical steps. Leakage in the wedged position leads to an underestimation of the wedged hepatic vein pressure, while peripheral measurements may result in an overestimation of the free hepatic vein pressure, since the catheter itself narrows the lumen, potentially inducing a hemodynamically relevant stenosis [34, 35•]. In both situations, HVPG might be underestimated. Sedation, if used at all, should be restricted to low doses of midazolam $(0.02 \mathrm{mg} / \mathrm{kg}$ body weight) [36], since higher doses or deep analgosedation with propofol/remifentanil impacts pressure measurements [37]. Finally, if high-quality pressure tracings are obtained, the interobserver agreement is excellent: In the subgroup of patients with CSPH included in a study by Tandon et al. [38•], the proportion of readings differing by $\geq 10 \%$ was only $9 \%$.

Besides procedure-related factors, several other important points have to be considered, especially when assessing the "chronic" HVPG response to NSBB: To avoid mixing the hemodynamic effects and the evolution of underlying etiology, liver disease should be stable, which is commonly not the case in alcoholic liver disease and patients undergoing etiological treatment.

Alcohol intake leads to an acute increase in portal pressure [39]. Moreover, alcoholic hepatitis [40] and, in particular, acute-on-chronic liver failure (ACLF) are associated with a profound increase in HVPG, which is explained by a further rise in intrahepatic resistance [41].

In contrast, hepatitis $\mathrm{C}$ virus (HCV) eradication promptly ameliorates portal hypertension [42•, 43•] in the majority of patients, most likely due to a decrease in hepatic inflammation [44•]. Hepatic inflammation increases the vascular tone, which is commonly referred to as the dynamic component of intrahepatic resistance [45]. This initial rapid decline might be followed by a further decrease in HVPG on the long-term [46, 47.], potentially indicative of the regression of liver fibrosis $[44 \bullet, 48 \cdot$ (i.e., the structural component of increased intrahepatic resistance). Similarly, HBV suppression by nucleotide analogue treatment for 12 months led to a substantial decrease in HVPG [49॰], which might be followed by further decreases due to liver fibrosis regression [50]. Owing to limited long-term data and considerable interindividual discrepancies, it is hard to determine whether and at what time point HVPG reaches a stable value after successful antiviral therapy $[51 \cdot]$.

Moreover, cofactors impacting portal hypertension are increasingly recognized. For instance, a 16-week lifestyle intervention comprising diet and physical exercise has been shown to lead to significant decreases in HVPG in obese patients with portal hypertension, particularly those achieving $\geq 10 \%$ of weight loss [52•].

Therefore, the assessment of "acute," or possibly, early "chronic" HVPG response to NSBB therapy may be preferred, if HVPG response-guided NSBB therapy is the main objective and if there is uncertainty about whether the underlying etiology and/or cofactors are stable.

\section{Benefits of HVPG Response-Guided NSBB Therapy}

Several studies provide evidence supporting the use of HVPG-guided NSBB treatment; however, only four studies were randomized controlled trials (RCT) [26, 53••, 54, 55••]. The main findings and information on effect size are summarized in Table 2.

Villanueva and co-workers conducted the only two trials providing direct evidence for a clinical benefit of a HVPGguided approach. First, they randomized $n=59$ patients to HVPG-guided therapy (nadolol plus ISMN; the latter being changed to prazosin in patients with hemodynamic nonresponse) or nadolol plus endoscopic variceal ligation (EVL) [54]. Prazosin was able to induce hemodynamic response in non-responders to nadolol plus ISMN. Further, HVPG response was linked to a decrease in bleeding. However, this study has been underpowered to directly detect a potential clinically meaningful benefit of the HVPG-guided treatment approach. In their second study [53・•], 169 patients in 
Table 2 Studies evaluating the benefits of hepatic venous pressure gradient (HVPG) response-guided non-selective beta-blocker (NSBB) therapy

\begin{tabular}{|c|c|c|c|c|c|}
\hline Study & Number of patients & Initial treatment & $\begin{array}{l}\text { Treatment of HVPG } \\
\text { non-responders }\end{array}$ & $\begin{array}{l}\text { Setting/patient } \\
\text { characteristics }\end{array}$ & Remarks/key findings \\
\hline $\begin{array}{l}\text { Bureau et al. } \\
\text { Hepatology } 2002 \\
\text { [56] }\end{array}$ & $\begin{aligned} n & =34 \\
n & =21 \\
& \text { HVPG-non-respon- } \\
& \text { ders }\end{aligned}$ & $\begin{array}{l}\text { Propranolol (fixed } \\
\text { dose of } 160 \mathrm{mg} \\
\text { q.a.d.); } \\
\text { "Chronic" HVPG } \\
\text { response (median: } \\
4 \text { days) }\end{array}$ & Propranolol + ISMN & $\begin{array}{l}\text { Primary prophylaxis } \\
\quad(n=14 \text {; all high-risk) } \\
\text { and secondary } \\
\text { prophylaxis }(n=20) \\
\text { HVPG } \geq 12 \mathrm{mmHg}\end{array}$ & $\begin{array}{l}33 \% \text { of hemodynamic } \\
\text { non-responders to propranolol } \\
\text { responded to } \\
\text { propranolol + ISMN; } \\
\text { improvement of overall } \\
\text { hemodynamic response rate } \\
\text { from } 38 \text { to } 59 \% \text {; } \\
A V B \text { : decreased if HVPG } \\
\text { response }\end{array}$ \\
\hline $\begin{array}{l}\text { González et al. } \\
\text { Hepatology } 2006 \\
\text { [28] }\end{array}$ & $\begin{array}{l}n=50 ; \\
n=42 \text { with } \\
\quad \text { information on } \\
\text { HVPG response; } \\
n=1010-19 \% \\
\quad \text { decrease, "partial } \\
\quad \text { responders"; } \\
n=8<10 \% \text { decrease, } \\
\quad \text { "non-responders" }\end{array}$ & $\begin{array}{l}\text { Nadolol (titrated } \\
\text { according to } \\
\text { HR) + ISMN; } \\
\text { "Chronic" HVPG } \\
\text { response (15 days) }\end{array}$ & $\begin{array}{l}\text { "Partial } \\
\text { responders": } \\
\text { add-on EVL; } \\
\text { "Non-responders": } \\
\text { TIPS }\end{array}$ & Secondary prophylaxis & $\begin{array}{l}\text { Patients with alcoholic cirrhosis } \\
\text { more likely to achieve HVPG } \\
\text { response; } 12 \% \text { of patients bled } \\
\text { before HVPG response } \\
\text { assessment; } \\
\text { Bleeding: comparable between } \\
\text { groups (limited sample size), } \\
\text { numerically } \\
\text { "non-responders"-_ } \\
\text { TIPS < "responders" } \\
\text { (nadolol + ISMN) < "partial } \\
\text { responders" } \\
\text { (nadolol + ISMN + EVL) }\end{array}$ \\
\hline $\begin{array}{l}\text { Villanueva et al. } \\
\text { Aliment } \\
\text { Pharmacol } \\
\text { Ther } 2009 \text { [54] }\end{array}$ & $\begin{array}{c}n=59 \text { randomized to } \\
\text { HVPG-guided } \\
\text { therapy }(n=30) \text { vs. } \\
\text { nadolol }+\mathrm{EVL}\end{array}$ & $\begin{array}{l}\text { Nadolol (titrated by } \\
\text { HR) + ISMN; } \\
\text { 1st "chronic" HVPG } \\
\text { response } \\
\text { (2-4 weeks); } \\
\text { 2nd "chronic" HVPG } \\
\text { response } \\
\text { (1-2 months after } \\
\text { 1st) }\end{array}$ & Nadolol + prazosin & Secondary prophylaxis & $\begin{array}{l}\text { Nadolol + prazosin decreased } \\
\text { HVPG in hemodynamic } \\
\text { non-responders to } \\
\text { nadolol + ISMN; } \\
\text { Bleeding: decreased if HVPG } \\
\text { response in HVPG-guided } \\
\text { therapy arm but not in } \\
\text { nadolol + EVL arm, increased } \\
\text { in the HVPG-guided arm }\end{array}$ \\
\hline $\begin{array}{l}\text { González et al. } \\
\text { Dig Liver Dis } \\
2012 \text { [27] }\end{array}$ & $\begin{array}{l}n=53 \\
n=48 \text { with } \\
\quad \text { information on } \\
\quad \text { HVPG response; } \\
\quad n=24 \text { HVPG } \\
\text { non-responders }\end{array}$ & $\begin{array}{l}\text { Nadolol (titrated } \\
\text { according to } \\
\text { HR) + ISMN; } \\
\text { "Chronic" HVPG } \\
\text { response (mean: } \\
13.4 \text { days) }\end{array}$ & Add-on EVL & Secondary prophylaxis & $\begin{array}{l}9 \% \text { of patients bled before HVPG } \\
\text { response assessment; } \\
\text { Bleeding: } 9 \% / 12 \% \text { in HVPG } \\
\text { responders (nadolol + ISMN) } \\
\text { vs. } 4 \% / 4 \% \text { in HVPG } \\
\text { non-responders } \\
\text { (nadolol + ISMN + EVL) at } \\
1 / 2 \text { years; } \\
\text { Mortality: decreased if HVPG } \\
\text { response }\end{array}$ \\
\hline $\begin{array}{l}\text { Reiberger et al. } \\
\text { Gut } 2013 \text { [57] }\end{array}$ & $\begin{array}{l}n=104 ; \\
n=94 \text { with } \\
\quad \text { information on } \\
\text { HVPG response; } \\
n=67 \text { HVPG } \\
\quad \text { non-responders }\end{array}$ & $\begin{array}{l}\text { Propranolol (titrated } \\
\text { according to HR } \\
\text { and SAP); } \\
\text { 1st "chronic" HVPG } \\
\text { response } \\
\text { (4 weeks); } \\
\text { 2nd "chronic" HVPG } \\
\text { response } \\
\text { (1-2 months after } \\
\text { 1st) }\end{array}$ & $\begin{array}{l}\text { Carvedilol } \\
\quad(6.25-50 \mathrm{mg} /- \\
\text { day); } \\
\text { EVL monotherapy } \\
\text { if non-responder } \\
\text { to carvedilol }\end{array}$ & $\begin{array}{l}\text { Primary prophylaxis } \\
\text { (small: } 39 \% \text { or large: } \\
61 \% \text { varices, red wale } \\
\text { marks: } 31 \% \text { ); } \\
\text { HVPG } \geq 12 \mathrm{mmHg}\end{array}$ & $\begin{array}{l}\text { Carvedilol decreased HVPG in } \\
\text { hemodynamic non-responders } \\
\text { to propranolol; } \\
57 \% \text { of patients non-responsive/ } \\
\text { intolerant to propranolol } \\
\text { responded to carvedilol; } \\
\text { Improvement of overall } \\
\text { hemodynamic response rate } \\
\text { from } 36 \text { to } 72 \% \text {; } \\
\text { AVB: } 11 \% \text { (propranolol)/8\% } \\
\text { (carvedilol) in HVPG } \\
\text { responders vs. } 24 \% \text { in } \\
\text { non-responders (EVL); } \\
\text { Ascites: decreased } \\
\text { Hepatic decompensation: trend } \\
\text { towards decrease } \\
\text { Mortality: decreased }\end{array}$ \\
\hline
\end{tabular}


Table 2 (continued)

\begin{tabular}{|c|c|c|c|c|c|}
\hline Study & Number of patients & Initial treatment & $\begin{array}{l}\text { Treatment of HVPG } \\
\text { non-responders }\end{array}$ & $\begin{array}{l}\text { Setting/patient } \\
\text { characteristics }\end{array}$ & Remarks/key findings \\
\hline $\begin{array}{l}\text { Gastroenterology } \\
2015 \text { [26] }\end{array}$ & $\begin{array}{l}n=185 \text { randomized to } \\
\text { HVPG-guided } \\
\text { therapy }(n=95) \text { vs. } \\
\text { TIPS; } \\
n=76 \text { with } \\
\text { information on } \\
\text { HVPG response; } \\
n=44 \text { HVPG } \\
\text { non-responders }\end{array}$ & $\begin{array}{l}\text { Propranolol (titrated } \\
\text { according to } \\
\text { HR) + ISMN; } \\
\text { "Chronic" HVPG } \\
\text { response (14 days) }\end{array}$ & & & $\begin{array}{l}5 \% \text { of patients bled before HVPG } \\
\text { response assessment; } \\
\text { Bleeding: } 26 \% \text { in } \\
\text { nadolol + ISMN/EVL } \\
\text { monotherapy arm vs. } 7 \% \text { in } \\
\text { TIPS arm at } 2 \text { years, trend } \\
\text { towards decrease in HVPG } \\
\text { responders vs. non-responders; } \\
\text { Mortality: comparable }\end{array}$ \\
\hline $\begin{array}{l}\text { Kirnake et al. } \\
\text { J Clin Experiment } \\
\text { Hepatol } 2016 \\
{[25]}\end{array}$ & $\begin{array}{l}\mathrm{n}=69 \\
n=76 \text { with } \\
\text { information on } \\
\text { "acute" HVPG } \\
\text { response; } \\
n=23 \text { "acute" HVPG } \\
\text { non-responders }\end{array}$ & $\begin{array}{l}\text { “Acute" HVPG } \\
\text { response to p.o. } \\
\text { carvedilol } \\
(25 \mathrm{mg}) ; \\
\text { Carvedilol } \\
\text { (12.5 mg/day); } \\
\text { "Chronic" HVPG } \\
\text { response (median: } \\
6 \text { months) }\end{array}$ & EVL monotherapy & $\begin{array}{l}\text { Primary ( } n=25 \text {; small: } \\
22 \% \text { or large: } 78 \% \\
\text { varices, red wale } \\
\text { marks: } 29 \%) \text { and } \\
\text { secondary } \\
\text { prophylaxis }(n=44) \text {; } \\
\text { HVPG } \geq 12 \mathrm{mmHg}\end{array}$ & $\begin{array}{l}\text { Bleeding: trend towards decrease } \\
\text { if "acute" HVPG response (vs. } \\
\text { EVL monotherapy); } \\
\text { Ascites: Comparable; } \\
\text { HE: comparable; } \\
\text { Mortality: comparable; } \\
\text { Maintenance of hemodynamic } \\
\text { response: } 92 \%, 70 \% \text { in } \\
\text { intention-to-treat analysis }\end{array}$ \\
\hline $\begin{array}{l}\text { Villanueva et al. } \\
\text { Hepatology } 2017 \\
{[53 \bullet \bullet]}\end{array}$ & $\begin{array}{c}n=169 \text { randomized to } \\
\text { HVPG-guided } \\
\text { therapy }(n=84) \text { vs. } \\
\text { nadolol plus } \\
\text { ISMN + EVL; } \\
n=70 \text { HVPG } \\
\text { non-responders }\end{array}$ & $\begin{array}{l}\text { “Acute" HVPG } \\
\text { response to i.v. } \\
\text { propranolol } \\
(0.15 \mathrm{mg} / \mathrm{kg}) ; \\
\text { Nadolol (titrated } \\
\text { according to HR); } \\
\text { 1st "chronic" HVPG } \\
\text { response } \\
\text { (2-4 weeks); 2nd } \\
\text { "chronic" HVPG } \\
\text { response } \\
\text { (2-4 weeks after } \\
\text { 1st) }\end{array}$ & $\begin{array}{l}\text { Nadolol + ISMN; } \\
\text { Nadolol + prazosin } \\
\text { If non-response to } \\
\text { nadolol + ISMN; } \\
\text { EVL until HVPG } \\
\text { response }\end{array}$ & Secondary prophylaxis & $\begin{array}{l}\text { Further decompensation: } \\
\text { HVPG-guided: } 52 \% \text { vs. } \\
\text { control: } 72 \% \text {; lower in patients } \\
\text { with "acute" or "chronic" } \\
\text { HVPG response to propranolol } \\
\text { or nadolol } \pm \text { ISMN; } \\
\text { Bleeding: HVPG-guided: } 19 \% \\
\text { vs. control: } 31 \% \text { (independent } \\
\text { association); } \\
\text { Ascites: comparable; } \\
\text { HE: trend towards decrease if } \\
\text { HVPG-guided; } \\
\text { Mortality: HVPG-guided: } 29 \% \\
\text { vs. control: } 43 \% \text { (independent } \\
\text { association); lower in patients } \\
\text { with "acute" or "chronic" } \\
\text { HVPG response to propranolol } \\
\text { or nadolol } \pm \text { ISMN }\end{array}$ \\
\hline $\begin{array}{l}\text { Villanueva et al. } \\
\text { Lancet } 2019 \\
{[55 \bullet \cdot]}\end{array}$ & $\begin{array}{c}n=201 \text { randomized to } \\
\text { HVPG-guided } \\
\text { therapy vs. placebo }\end{array}$ & $\begin{array}{l}\text { “Acute" HVPG } \\
\text { response to i.v. } \\
\text { propranolol } \\
(0.15 \mathrm{mg} / \mathrm{kg}) ;\end{array}$ & Carvedilol & $\begin{array}{l}\text { Pre-primary prophylaxis } \\
\text { in patients with } \\
\mathrm{HVPG} \geq 10 \mathrm{mmHg} \\
\text { or primary } \\
\text { prophylaxis }\end{array}$ & $\begin{array}{l}\text { Hepatic decompensation or } \\
\text { death: trend towards decrease; } \\
\text { Hepatic decompensation or } \\
\text { liver-related death: decreased; } \\
9 \% \text { in HVPG-guided vs. } 20 \% \\
\text { in placebo arm }\end{array}$ \\
\hline
\end{tabular}

ISMN, isosorbide mononitrate; AVB, acute variceal bleeding; EVL, endoscopic variceal ligation; HR, heart rate; TIPS, transjugular intrahepatic portosystemic shunt; SAP, systolic arterial pressure; HE, hepatic encephalopathy

secondary prophylaxis were randomized to either HVPGguided therapy or nadolol plus ISMN plus EVL. In the HVPG-guided arm, ISMN was replaced by prazosin in the case of HVPG non-response to nadolol plus ISMN. Moreover, EVL was performed until HVPG response was achieved. Importantly, this study demonstrated that HVPGguided therapy might improve mortality. Another RCT allocated patients in secondary prophylaxis to HVPG-guided therapy or TIPS [26]. Using propranolol plus ISMN ("chronic" HVPG responders) or EVL monotherapy ("chronic" HVPG non-responders), the bleeding rate in the HVPG-guided therapy arm was only $26 \%$ at 2 years, however, still higher than that in the TIPS arm (7\% in 2 years). Importantly, this did not result in a difference in mortality. Of note, nearly half of the patients included in this study were Child-Turcotte-Pugh stage A. Nevertheless, the relatively low bleeding/mortality rates could also be interpreted as indirect evidence for the effectiveness of the HVPG-guided approach. In the fourth RCT, which was restricted to patients with CSPH in the setting of preprimary prophylaxis (no or small varices without red wale 
marks), treatment with propranolol (HVPG decrease $\geq 10 \%$ to i.v. propranolol) or carvedilol (hemodynamic non-responders to i.v. propranolol) decreased (vs. placebo) the risks of hepatic decompensation or liver-related death, mostly by decreasing the incidence of ascites [55••]. Importantly, the statistical analysis of this study also followed the concept of competing risks. Next to the use of HVPG-guided therapy, improvements in patient selection, such as the exclusion of patients without CSPH and inclusion of patients with low-risk varices, may have contributed to the positive result of this trial.

Furthermore, HVPG-guided therapy has been applied in a series of clinical trials without randomized treatment assignment. Importantly, there is considerable heterogeneity in the studied patient populations (i.e., primary or secondary prophylaxis or a combination of both), the initial treatments (propranolol $[56,57]$ or nadolol monotherapy [53••] as well as propranolol [26] or nadolol plus ISMN [27, 28, 54]), the time points of the first assessment of "chronic" HVPG response (ranging from 4 days [56] to 4 weeks [57]), and the alternative treatment strategies applied in HVPG non-responders (carvedilol [57], propranolol [26, 56] or nadolol plus ISMN [53••], nadolol plus prazosin [53••, 54], [add-on] EVL [26-28, 53••, 57], or even TIPS [28]). Importantly, neither ISMN nor prazosin are considered as first-line treatments for portal hypertension $[6,7,58 \bullet, 59]$ and there are concerns about the safety of these potent vasodilators, which substantially limits the clinical applicability of HVPG-guided treatment strategies using these drugs. In contrast, carvedilol, a NSBB with additional anti- $\alpha 1$-adrenergic activity $[3 \bullet \bullet, 5 \bullet \bullet]$, is a first-line option for primary prophylaxis of variceal bleeding $[6,7,58 \bullet$, 59]. Using carvedilol in "chronic" hemodynamic nonresponders to propranolol doubled the overall rate of HVPG response (from 36 to $72 \%$ ) and, thus, decreased the incidence of AVB, development/worsening of ascites, and mortality in HVPG responders, as compared to EVL monotherapy [57]. Still, carvedilol is not recommended for secondary prophylaxis by Baveno VI consensus [6] and the American Association for the Study of Liver Diseases (AASLD) guidelines [58•]. This is due to the absence of adequately designed trials comparing carvedilol to NSBB plus EVL, the current standard of care in this setting. Moreover, carvedilol should be avoided in patients with severe ascites $[3 \bullet \bullet, 5 \bullet \bullet, 7,58 \bullet, 59]$ restricting its use to patients with less severe hepatic dysfunction.

\section{Limitations of HVPG Response-Guided Therapy}

HVPG response is sensitive in predicting (recurrent) AVB but, in general, lacks specificity [60]. This is particularly problematic in patients on primary (or even pre-primary) prophylaxis, as the incidence of (further) hepatic decompensation is considerably lower, when compared to secondary prophylaxis. In these settings, "chronic" HVPG non-response has a particularly low positive predictive value (PPV). For instance, in a meta-analysis by Villanueva et al. [61], the PPV for variceal bleeding was only $32 \%$ in primary prophylaxis, while the negative predictive value (NPV) was as high as $94 \%$. However, the positive likelihood ratio, which is not affected by the prevalence of the condition, was still 2.01, which is comparable to secondary prophylaxis (2.1) [60]. Importantly, the PPV in primary prophylaxis has improved with the Baveno VI consensus [6], which, as mentioned previously, adopted the more specific 10\% cut-off for both "acute" and "chronic" assessments (e.g., PPV increase from 24 to about $42 \%$ [20]). Still, the PPV remains suboptimal, indicating that, at least in primary prophylaxis, it is not justified to subject HVPG non-responders to more aggressive and eventually harmful treatment strategies, such as TIPS [26, 28].

Moreover, NSBB seems to exert additional, so-called nonhemodynamic effects, which might not be reflected by HVPG response. NSBB treatment decreases markers of intestinal permeability and bacterial translocation, independently of hemodynamic response [62]. This finding provides a convincing pathophysiologic mechanism for the reduced risk of SBP development observed in NSBB-treated patients, even in the case of HVPG non-response [63, 64]. However, other studies suggested that HVPG response further decreases the risk of SBP (vs. hemodynamic non-response), which could be explained by its effect on the occurrence/worsening of ascites [16, 19, 20, 23]. Only recently, another potential nonhemodynamic effect has been proposed: Mookerje et al. [65] investigated the impact of NSBB treatment (mostly propranolol at a low median dose of $40 \mathrm{mg}$ /day) on survival in patients who went on to develop ACLF in the CANONIC study. Interestingly, ACLF was less severe and showed a higher probability of improvement in the NSBB group, which also translated into a mortality benefit. Since patients in the NSBB group had a lower white cell count, the authors hypothesized that NSBB treatment modulates the systemic inflammatory response driving ACLF. However, causality has yet to be demonstrated, especially since NSBB treatment had already been stopped prior to inclusion or discontinued after inclusion in the vast majority of patients.

Although it is clear that NSBB treatment is particularly beneficial in HVPG responders, these potential nonhemodynamic effects question the discontinuation of NSBB treatment in HVPG non-responders without clinically significant side effects, which has been performed in some of the studies investigating HVPG-guided therapy approaches. This might be particularly problematic in secondary prophylaxis, in which NSBB are the key component of combination treatment to reduce mortality $[66 \bullet, 67]$.

HVPG measurement is generally safe and well-tolerated [68, 69]; nevertheless, its clinical use is limited by its invasiveness and its availability mostly restricted to academic 
centers. Thus, the development of non-invasive methods for monitoring NSBB efficacy should be promoted to facilitate personalized medicine in the field of portal hypertension $[70 \bullet \bullet, 71]$.

\section{Non-Invasive Markers for HVPG Response}

Initial ultrasound (US)-based attempts, such as Doppler-based assessments, did not sufficiently reflect (changes in) HVPG, and, thus, cannot substitute HVPG measurement [70••]. More recently, sophisticated contrast-enhanced US-based methods have shown encouraging results and are currently investigated in clinical trials.

Liver stiffness assessed by US-based elastography methods, such as transient elastography (TE), might be useful for monitoring the evolution of portal hypertension after etiological therapy in patients without evidence of CSPH prior to the removal of the primary etiological factor $[42 \bullet, 72]$. However, liver stiffness measured by US-based elastography methods is of limited value for assessing HVPG response due to its weak correlation with HVPG in patients with HVPG values $\geq 10$ to $\geq 12 \mathrm{mmHg}$ [73], i.e., patients which are considered as candidates for response-guided NSBB therapy. Of note, there is evidence suggesting that changes in liver stiffness under/following portal pressure-lowering treatments (i.e., NSBB [71] and transjugular intrahepatic portosystemic shunt [74]) hold prognostic information even beyond their relation to portal pressure; however, the underlying pathophysiological mechanisms are yet to be fully elucidated.

Spleen stiffness assessed by US-based elastography showed very promising results with a numerically (TE [75]) or even statistically significantly (point shear-wave elastography (pSWE)/virtual touch quantification (VTQ) [76]) stronger (vs. liver stiffness) correlation with HVPG. This might be explained by the fact that spleen stiffness more directly reflects portal hypertension, as it is mostly a measure of portal venous congestion, while liver stiffness is also strongly influenced by liver fibrosis [70 • $]$ and other factors, including arterial blood pressure $[71,77]$. However, the superiority of spleen stiffness (vs. liver stiffness) has not been confirmed by another study using both TE and twodimensional shear-wave elastography (2D-SWE)/supersonic imaging (SSI) [78]. Moreover, similar to liver stiffness, the strength of the correlation between spleen stiffness and HVPG decreases with increasing severity of portal hypertension. In a recent study using 2D-SWE/SSI [79], for instance, Spearman's $\rho$ in patients with HVPG values $\geq 12 \mathrm{mmHg}$ was 0.464 , indicating a positive correlation of only moderate strength. In contrast, a substantially stronger correlation was observed in the overall study population $(\rho=0.665)$.
Despite the limited strength of correlation between liver/ spleen stiffness and HVPG in patients with HVPG values $\geq$ $12 \mathrm{mmHg}$, three studies evaluated the performance of changes in liver/spleen stiffness for monitoring the dynamics of HVPG during NSBB treatment. The first study by Choi et al. [80] observed a strong correlation between changes in HVPG and liver stiffness measured by 2D-SWE/SSI and also reported an AUROC of 0.794 for diagnosing HVPG response. However, the significance of the findings of this study is limited by the small number $(n=23)$ of patients undergoing a follow-up HVPG measurement on NSBB treatment. In a second study by Kim et al. [81••], a model based on the change in spleen stiffness (baseline vs. carvedilol; median dose: $25 \mathrm{mg}$ /day), as assessed by 106 patients with high-risk varices undergoing paired pSWE/VTQ and HVPG measurements, had an AUROC of 0.803 . In the independent validation cohort ( $n=$ 63; median dose: $12.5 \mathrm{mg} /$ day), the AUROC was even numerically higher (0.848). Accordingly, spleen stiffness measurement shows some promise as a non-invasive surrogate of HVPG response.

However, even in highly standardized study settings, the diagnostic performance of US-based elastography methods for HVPG response is suboptimal. Importantly, these methods measure portal venous congestion (spleen stiffness; the result of increased intrahepatic resistance and portal venous blood flow) and liver fibrosis (liver stiffness; static component of increased intrahepatic resistance) but do not specifically assess hyperdynamic circulation (i.e., increased cardiac output and splanchnic vasodilatation) [70•0]. However, these features of hyperdynamic circulation are the main therapeutic target of conventional NSBB $[3 \cdot \bullet, 5 \bullet \bullet]$. Accordingly, magnetic resonance imaging (MRI)-based blood flow measurements may be considered a more direct, and, thus, highly promising approach for monitoring hemodynamic response to NSBB. A MRI-derived model of HVPG combining spin-echo echo planar imaging $T_{1}$ relaxation time and splenic artery velocity showed a strong positive correlation with HVPG (Spearman's $\rho=0.9$ ), which was maintained in the subgroup of patients with CSPH (Spearman's $\rho=0.85$ ) [82•]. Nevertheless, the ability of MRI-derived parameters to monitor NSBB-induced changes in HVPG has yet to be investigated.

Finally, non-imaging-based surrogates of HVPG response have been developed. Ras homolog family member $\mathrm{A}$ and Rho-kinase 2 transcription in the mucosa of the antrum [83] as well as serum levels of a phosphatidylcholine and a free fatty acid (AUROC: 0.801 ) [84•] have been shown to predict HVPG response to propranolol.

In conclusion, the performance of these novel, noninvasive approaches for predicting HVPG response warrants further evaluation, since non-invasive surrogates with high diagnostic accuracy might pave the way for NSBB treatment individualization outside of centers with sufficient resources and expertise for HVPG-guided therapy [6, 7]. 


\section{Conclusions}

HVPG response reduces the risks of AVB, the development of hepatic decompensation due to ascites and its complications, and, finally, even mortality. Clinical benefits of HVPG response have been established throughout a broad spectrum of ACLD severity, ranging from clinical stage 1 (compensated without varices) with CSPH to stage 5 (further hepatic decompensation). Accordingly, the assessment of HVPG response provides important prognostic information. In hemodynamic non-responders to NSBB, their effectiveness is suboptimal, although there is increasing evidence for non-hemodynamic effects of NSBB therapy. Accordingly, it is unclear whether NSBB therapy should be discontinued in HVPG nonresponders with good treatment tolerance. HVPG-guided NSBB therapy facilitates personalized medicine in the field of portal hypertension. Of note, the "chronic" HVPG response is strongly influenced by dynamics of the underlying etiology, and, thus, may not always mirror the effect of a pharmaceutical intervention. This might have implications for HVPG response-guided NSBB therapy. Patients with non-response to conventional NSBB might benefit from carvedilol, which is more potent in decreasing HVPG. Furthermore, hemodynamic non-responders may also benefit from (the addition of) other HVPG-lowering drugs which are in clinical development, and, depending on the clinical setting, complimentary or alternative treatment strategies. Nevertheless, the clinical use of HVPG measurement is limited by its invasiveness and its availability is mostly restricted to academic centers. Accordingly, the development of non-invasive surrogates of HVPG response is of utmost importance.

Funding Open access funding provided by Medical University of Vienna. No funding specific to this review was received. M.M. is supported by the Andrew K. Burroughs short-term training fellowship of the European Association for the Study of the Liver.

\section{Compliance with Ethical Standards}

Conflict of Interest Mattias Mandorfer served as a speaker and/or consultant and/or advisory board member for AbbVie, Bristol-Myers Squibb, Gilead, and W. L. Gore \& Associates and received travel support from AbbVie, Bristol-Myers Squibb, and Gilead. Virginia Hernández-Gea served as a speaker for W. L. Gore \& Associates. Thomas Reiberger served as a speaker and/or consultant and/or advisory board member for AbbVie, Bayer, Boehringer Ingelheim, Gilead, Intercept, MSD, Roche, Siemens, and W. L. Gore \& Associates and received grants/research support from AbbVie, Boehringer Ingelheim, Gilead, MSD, Philips, and W. L. Gore \& Associates as well as travel support from Boehringer Ingelheim, Gilead, and Roche. Juan Carlos García-Pagán served as a speaker and/or advisory board member for Cook and W. L. Gore \& Associates and received grants/research support from Conatus, Exalenz, Novartis, and Theravance.

Human and Animal Rights and Informed Consent This article does not contain any studies with human or animal subjects performed by any of the authors.
Open Access This article is distributed under the terms of the Creative Commons Attribution 4.0 International License (http:// creativecommons.org/licenses/by/4.0/), which permits unrestricted use, distribution, and reproduction in any medium, provided you give appropriate credit to the original author(s) and the source, provide a link to the Creative Commons license, and indicate if changes were made.

\section{References}

Papers of particular interest, published recently, have been highlighted as:

- Of importance

•- Of major importance

1. Abraldes JG, Sarlieve P, Tandon P. Measurement of portal pressure. Clin Liver Dis. 2014;18(4):779-92. https://doi.org/10.1016/j.cld. 2014.07.002.

2. La Mura V, Nicolini A, Tosetti G, Primignani M. Cirrhosis and portal hypertension: the importance of risk stratification, the role of hepatic venous pressure gradient measurement. World J Hepatol. 2015;7(4):688-95. https://doi.org/10.4254/wjh.v7.i4.688.

3.• Mandorfer M, Reiberger T. Beta blockers and cirrhosis, 2016. Dig Liver Dis. 2017;49(1):3-10. https://doi.org/10.1016/j.dld.2016.09. 013 Detailed review article on the current knowledge on NSBB therapy.

4. Mandorfer M, Peck-Radosavljevic M, Reiberger T. Prevention of progression from small to large varices: are we there yet? An updated meta-analysis. Gut. 2017;66(7):1347-9. https://doi.org/10. 1136/gutjnl-2016-312814 Updated meta-analysis on the use of NSBB for preventing the progression from small to large varices.

5.• Reiberger T, Mandorfer M. Beta adrenergic blockade and decompensated cirrhosis. J Hepatol. 2017;66(4):849-59. https://doi.org/ 10.1016/j.jhep.2016.11.001 Detailed review article on the current knowledge on NSBB therapy.

6. de Franchis R, Baveno VIF. Expanding consensus in portal hypertension: report of the Baveno VI consensus workshop: stratifying risk and individualizing care for portal hypertension. J Hepatol. 2015;63(3):743-52. https://doi.org/10.1016/j.jhep.2015.05.022.

7.• Reiberger T, Puspok A, Schoder M, Baumann-Durchschein F, Bucsics T, Datz C, et al. Austrian consensus guidelines on the management and treatment of portal hypertension (Billroth III). Wien Klin Wochenschr. 2017;129(Suppl 3):135-58. https://doi. org/10.1007/s00508-017-1262-3 Austrian consensus guidelines on portal hypertension, including a chapter on HVPGmeasurement.

8. D'Amico G, Pagliaro L, Bosch J. Pharmacological treatment of portal hypertension: an evidence-based approach. Semin Liver Dis. 1999;19(4):475-505. https://doi.org/10.1055/s-20071007133.

9. Groszmann RJ, Bosch J, Grace ND, Conn HO, Garcia-Tsao G, Navasa M, et al. Hemodynamic events in a prospective randomized trial of propranolol versus placebo in the prevention of a first variceal hemorrhage. Gastroenterology. 1990;99(5):1401-7.

10. Feu F, Garcia-Pagan JC, Bosch J, Luca A, Teres J, Escorsell A, et al. Relation between portal pressure response to pharmacotherapy and risk of recurrent variceal haemorrhage in patients with cirrhosis. Lancet. 1995;346(8982):1056-9.

11. Abraldes JG, Albillos A, Banares R, Turnes J, Gonzalez R, GarciaPagan JC, et al. Simvastatin lowers portal pressure in patients with cirrhosis and portal hypertension: a randomized controlled trial. 
Gastroenterology. 2009;136(5):1651-8. https://doi.org/10.1053/j. gastro.2009.01.043.

12. Pollo-Flores P, Soldan M, Santos UC, Kunz DG, Mattos DE, da Silva AC, et al. Three months of simvastatin therapy vs. placebo for severe portal hypertension in cirrhosis: a randomized controlled trial. Dig Liver Dis. 2015;47(11):957-63. https://doi.org/10.1016/ j.dld.2015.07.156.

13. Bishnu S, Ahammed SM, Sarkar A, Hembram J, Chatterjee S, Das $\mathrm{K}$, et al. Effects of atorvastatin on portal hemodynamics and clinical outcomes in patients with cirrhosis with portal hypertension: a proof-of-concept study. Eur J Gastroenterol Hepatol. 2018;30(1): 54-9. https://doi.org/10.1097/MEG.0000000000001006.

14. Vilaseca M, Guixe-Muntet S, Fernandez-Iglesias A, Gracia-Sancho J. Advances in therapeutic options for portal hypertension. Ther Adv Gastroenterol. 2018;11:1756284818811294. https://doi.org/ $10.1177 / 1756284818811294$ Detailed review article on emerging medical therapies for portal hypertension.

15. Merkel C, Bolognesi M, Sacerdoti D, Bombonato G, Bellini B, Bighin R, et al. The hemodynamic response to medical treatment of portal hypertension as a predictor of clinical effectiveness in the primary prophylaxis of variceal bleeding in cirrhosis. Hepatology. 2000;32(5):930-4. https://doi.org/10.1053/jhep.2000.19322.

16. Abraldes JG, Tarantino I, Turnes J, Garcia-Pagan JC, Rodes J, Bosch J. Hemodynamic response to pharmacological treatment of portal hypertension and long-term prognosis of cirrhosis. Hepatology. 2003;37(4):902-8. https://doi.org/10.1053/jhep.2003. 50133.

17. Villanueva C, Lopez-Balaguer JM, Aracil C, Kolle L, Gonzalez B, Minana J, et al. Maintenance of hemodynamic response to treatment for portal hypertension and influence on complications of cirrhosis. J Hepatol. 2004;40(5):757-65. https://doi.org/10.1016/j. jhep.2004.01.017

18. Groszmann RJ, Garcia-Tsao G, Bosch J, Grace ND, Burroughs AK, Planas R, et al. Beta-blockers to prevent gastroesophageal varices in patients with cirrhosis. N Engl J Med. 2005;353(21):2254-61. https://doi.org/10.1056/NEJMoa044456.

19. Turnes J, Garcia-Pagan JC, Abraldes JG, Hernandez-Guerra M, Dell'Era A, Bosch J. Pharmacological reduction of portal pressure and long-term risk of first variceal bleeding in patients with cirrhosis. Am J Gastroenterol. 2006;101(3):506-12. https://doi.org/10. 1111/j.1572-0241.2006.00453.x.

20. Villanueva C, Aracil C, Colomo A, Hernandez-Gea V, LopezBalaguer JM, Alvarez-Urturi C, et al. Acute hemodynamic response to beta-blockers and prediction of long-term outcome in primary prophylaxis of variceal bleeding. Gastroenterology. 2009;137(1):119-28. https://doi.org/10.1053/j.gastro.2009.03.048.

21. La Mura V, Abraldes JG, Raffa S, Retto O, Berzigotti A, GarciaPagan JC, et al. Prognostic value of acute hemodynamic response to i.v. propranolol in patients with cirrhosis and portal hypertension. $\mathrm{J}$ Hepatol. 2009;51(2):279-87. https://doi.org/10.1016/j.jhep.2009. 04.015 .

22. Augustin S, Gonzalez A, Badia L, Millan L, Gelabert A, Romero A, et al. Long-term follow-up of hemodynamic responders to pharmacological therapy after variceal bleeding. Hepatology. 2012;56(2): 706-14. https://doi.org/10.1002/hep.25686.

23. Hernandez-Gea V, Aracil C, Colomo A, Garupera I, Poca M, Torras $\mathrm{X}$, et al. Development of ascites in compensated cirrhosis with severe portal hypertension treated with beta-blockers. Am J Gastroenterol. 2012;107(3):418-27. https://doi.org/10.1038/ajg. 2011.456.

24. D'Amico G, Morabito A, D'Amico M, Pasta L, Malizia G, Rebora $\mathrm{P}$, et al. Clinical states of cirrhosis and competing risks. J Hepatol. 2018;68(3):563-76. https://doi.org/10.1016/j.jhep.2017.10.020 Review article on the importance of competing risks in studies on ACLD.
25. Kirnake V, Arora A, Gupta V, Sharma P, Singla V, Bansal N, et al. Hemodynamic response to carvedilol is maintained for long periods and leads to better clinical outcome in cirrhosis: a prospective study. J Clin Exp Hepatol. 2016;6(3):175-85. https://doi.org/10.1016/j. jceh.2016.01.004.

26. Sauerbruch T, Mengel M, Dollinger M, Zipprich A, Rossle M, Panther E, et al. Prevention of rebleeding from esophageal varices in patients with cirrhosis receiving small-diameter stents versus hemodynamically controlled medical therapy. Gastroenterology. 2015;149(3):660-8 e1. https://doi.org/10.1053/j.gastro.2015.05. 011.

27. Gonzalez A, Augustin S, Dot J, Perez M, Abu-Suboh M, Romero A, et al. Adding banding ligation is effective as rescue therapy to prevent variceal rebleeding in haemodynamic non-responders to pharmacological therapy. Dig Liver Dis. 2012;44(1):55-60. https://doi.org/10.1016/j.dld.2011.07.019.

28. Gonzalez A, Augustin S, Perez M, Dot J, Saperas E, Tomasello A, et al. Hemodynamic response-guided therapy for prevention of variceal rebleeding: an uncontrolled pilot study. Hepatology. 2006;44(4):806-12. https://doi.org/10.1002/hep.21343.

29. Villanueva C, Albillos A, Genesca J, Abraldes JG, Calleja JL, Aracil C, et al. Development of hyperdynamic circulation and response to beta-blockers in compensated cirrhosis with portal hypertension. Hepatology. 2015;63:197-206. https://doi.org/10.1002/ hep. 28264.

30. Bosch J, Abraldes JG, Berzigotti A, Garcia-Pagan JC. The clinical use of HVPG measurements in chronic liver disease. Nat Rev Gastroenterol Hepatol. 2009;6(10):573-82. https://doi.org/10. 1038/nrgastro.2009.149.

31.• Reiberger T, Schwabl P, Trauner M, Peck-Radosavljevic M, Mandorfer M. Measurement of the hepatic venous pressure gradient and transjugular liver biopsy. J Vis Exp. 2019. https://www. jove.com/video/58819/measurement-hepatic-venous-pressuregradient-transjugular-liver Comprehensive protocol for HVPGmeasurement published in a visual format.

32. Zipprich A, Winkler M, Seufferlein T, Dollinger MM. Comparison of balloon vs. straight catheter for the measurement of portal hypertension. Aliment Pharmacol Ther. 2010;32(11-12):1351-6. https:// doi.org/10.1111/j.1365-2036.2010.04484.x.

33. Maleux G, Willems E, Fieuws S, Heye S, Vaninbroukx J, Laleman $\mathrm{W}$, et al. Prospective study comparing different indirect methods to measure portal pressure. J Vasc Interv Radiol. 2011;22(11):1553-8. https://doi.org/10.1016/j.jvir.2011.08.003.

34. Rossle M, Blanke P, Fritz B, Schultheiss M, Bettinger D. Free hepatic vein pressure is not useful to calculate the portal pressure gradient in cirrhosis: a morphologic and hemodynamic study. $\mathrm{J}$ Vasc Interv Radiol. 2016;27(8):1130-7. https://doi.org/10.1016/j. jvir.2016.03.028.

35. Bosch J, Garcia-Pagan JC. Calculating hepatic venous pressure gradient: feel free to stay free. J Vasc Interv Radiol. 2016;27(8): 1138-9. https://doi.org/10.1016/j.jvir.2016.03.048 Guidance for measuring correct free hepatic vein pressure values.

36. Steinlauf AF, Garcia-Tsao G, Zakko MF, Dickey K, Gupta T, Groszmann RJ. Low-dose midazolam sedation: an option for patients undergoing serial hepatic venous pressure measurements. Hepatology. 1999;29(4):1070-3. https://doi.org/10.1002/hep. 510290421.

37. Reverter E, Blasi A, Abraldes JG, Martinez-Palli G, Seijo S, Turon $F$, et al. Impact of deep sedation on the accuracy of hepatic and portal venous pressure measurements in patients with cirrhosis. Liver Int: Off J Int Assoc Stud Liver. 2014;34(1):16-25. https:// doi.org/10.1111/liv.12229.

38. Tandon P, Ripoll C, Assis D, Wongcharatrawee S, Groszmann RJ, Garcia-Tsao G. The interpretation of hepatic venous pressure gradient tracings - excellent interobserver agreement unrelated to experience. Liver Int: Off J Int Assoc Stud Liver. 2016;36(8):1160-6. 
https://doi.org/10.1111/liv.13065 Study indicating that the interobserver agreement for HVPG is excellent, if highquality pressure tracings are obtained.

39. Luca A, Garcia-Pagan JC, Bosch J, Feu F, Caballeria J, Groszmann RJ, et al. Effects of ethanol consumption on hepatic hemodynamics in patients with alcoholic cirrhosis. Gastroenterology. 1997;112(4): 1284-9.

40. Spahr L, Goossens N, Furrer F, Dupuis M, Vijgen S, Elkrief L, et al. A return to harmful alcohol consumption impacts on portal hemodynamic changes following alcoholic hepatitis. Eur J Gastroenterol Hepatol. 2018;30(8):967-74. https://doi.org/10.1097/MEG. 0000000000001148 .

41. Mehta G, Mookerjee RP, Sharma V, Jalan R. Systemic inflammation is associated with increased intrahepatic resistance and mortality in alcohol-related acute-on-chronic liver failure. Liver Int: Off J Int Assoc Stud Liver. 2015;35(3):724-34. https://doi.org/10.1111/ liv. 12559.

42. Mandorfer M, Kozbial K, Schwabl P, Freissmuth C, Schwarzer R, Stern R, et al. Sustained virologic response to interferon-free therapies ameliorates HCV-induced portal hypertension. J Hepatol. 2016;65(4):692-9. https://doi.org/10.1016/j.jhep.2016.05.027 Study on the impact of HCV cure on HVPG.

43. Lens S, Alvarado-Tapias E, Marino Z, Londono MC, E LL, Martinez J, et al. Effects of all-oral anti-viral therapy on HVPG and systemic hemodynamics in patients with hepatitis $\mathrm{C}$ virusassociated cirrhosis. Gastroenterology. 2017;153(5):1273-83 e1. https://doi.org/10.1053/j.gastro.2017.07.016 Study on the impact of HCV cure on HVPG.

44. Schwabl P, Mandorfer M, Steiner S, Scheiner B, Chromy D, Herac $\mathrm{M}$, et al. Interferon-free regimens improve portal hypertension and histological necroinflammation in HIV/HCV patients with advanced liver disease. Aliment Pharmacol Ther. 2017;45(1):13949. https://doi.org/10.1111/apt.13844 Study on the impact of HCV cure on HVPG.

45. Bosch J, Groszmann RJ, Shah VH. Evolution in the understanding of the pathophysiological basis of portal hypertension: how changes in paradigm are leading to successful new treatments. J Hepatol. 2015;62(1 Suppl):S121-30. https://doi.org/10.1016/j.jhep.2015.01. 003.

46. Lens S, Rincon D, Garcia-Retortillo M, Albillos A, Calleja JL, Banares R, et al. Association between severe portal hypertension and risk of liver decompensation in patients with hepatitis $\mathrm{C}$, regardless of response to antiviral therapy. Clin Gastroenterol Hepatol: Off Clin Pract J Am Gastroenterol Assoc. 2015. https:// doi.org/10.1016/j.cgh.2015.04.013.

47. Afdhal N, Everson GT, Calleja JL, McCaughan GW, Bosch J, Brainard DM, et al. Effect of viral suppression on hepatic venous pressure gradient in hepatitis $\mathrm{C}$ with cirrhosis and portal hypertension. J Viral Hepat. 2017;24(10):823-31. https://doi.org/10.1111/ jvh.12706 Study investigating the impact of viral (HCV) suppression on HVPG.

48. Mauro E, Crespo G, Montironi C, Londono MC, Hernandez-Gea V, Ruiz P, et al. Portal pressure and liver stiffness measurements in the prediction of fibrosis regression after sustained virological response in recurrent hepatitis C. Hepatology. 2018;67(5):1683-94. https:// doi.org/10.1002/hep.29557 Study on the impact of HCV cure on HVPG.

49. Manolakopoulos S, Triantos C, Theodoropoulos J, Vlachogiannakos J, Kougioumtzan A, Papatheodoridis G, et al. Antiviral therapy reduces portal pressure in patients with cirrhosis due to $\mathrm{HBeAg-negative} \mathrm{chronic} \mathrm{hepatitis} \mathrm{B} \mathrm{and} \mathrm{significant} \mathrm{portal}$ hypertension. J Hepatol. 2009;51(3):468-74. https://doi.org/10. 1016/j.jhep.2009.05.031 Study demonstrating that viral (HBV) suppression decreases HVPG.

50. Marcellin P, Gane E, Buti M, Afdhal N, Sievert W, Jacobson IM, et al. Regression of cirrhosis during treatment with tenofovir disoproxil fumarate for chronic hepatitis B: a 5-year open-label follow-up study. Lancet. 2013;381(9865):468-75. https://doi.org/ 10.1016/S0140-6736(12)61425-1.

51. Lens S, Berbel C, Forns X, García-Pagán JC. Portal hypertension reverses following successful antiviral treatment for HCV: fact or fiction? Curr Hepatol Rep. 2018;17(3):209-17. https://doi.org/10. 1007/s11901-018-0405-y Review article on the impact of HCV cure on HVPG

52. Berzigotti A, Albillos A, Villanueva C, Genesca J, Ardevol A, Augustin S, et al. Effects of an intensive lifestyle intervention program on portal hypertension in patients with cirrhosis and obesity: the SportDiet study. Hepatology. 2017;65(4):1293-305. https://doi. org/10.1002/hep.28992 Study investigating the impact of lifestyle changes on HVPG.

53.• Villanueva C, Graupera I, Aracil C, Alvarado E, Minana J, Puente $\mathrm{A}$, et al. A randomized trial to assess whether portal pressure guided therapy to prevent variceal rebleeding improves survival in cirrhosis. Hepatology. 2017;65:1693-707. https://doi.org/10.1002/hep. 29056. RCT on HVPG-guided therapy.

54. Villanueva C, Aracil C, Colomo A, Lopez-Balaguer JM, Piqueras M, Gonzalez B, et al. Clinical trial: a randomized controlled study on prevention of variceal rebleeding comparing nadolol + ligation vs. hepatic venous pressure gradient-guided pharmacological therapy. Aliment Pharmacol Ther. 2009;29(4):397-408. https://doi.org/ 10.1111/j.1365-2036.2008.03880.x.

55.• Villanueva C, Albillos A, Genescà J, Garcia-Pagan JC, Calleja JL, Aracil C, et al. $\beta$ blockers to prevent decompensation of cirrhosis in patients with clinically significant portal hypertension (PREDESCI): a randomised, double-blind, placebo-controlled, multicentre trial. Lancet. 2019;393(10181):1597-1608. https://doi. org/10.1016/S0140-6736(18)31875-0 RCT on HVPG-guided therapy in patients with CSPH but no or low-risk varices.

56. Bureau C, Peron JM, Alric L, Morales J, Sanchez J, Barange K, et al. "A La Carte" treatment of portal hypertension: adapting medical therapy to hemodynamic response for the prevention of bleeding. Hepatology. 2002;36(6):1361-6. https://doi.org/10.1053/jhep. 2002.36945.

57. Reiberger T, Ulbrich G, Ferlitsch A, Payer BA, Schwabl P, Pinter $\mathrm{M}$, et al. Carvedilol for primary prophylaxis of variceal bleeding in cirrhotic patients with haemodynamic non-response to propranolol. Gut. 2013;62(11):1634-41. https://doi.org/10.1136/gutjnl-2012304038.

58. Garcia-Tsao G, Abraldes JG, Berzigotti A, Bosch J. Portal hypertensive bleeding in cirrhosis: risk stratification, diagnosis, and management: 2016 practice guidance by the American Association for the Study of Liver Diseases. Hepatology. 2017;65(1):310-35. https://doi.org/10.1002/hep.28906 American Association for the Study of Liver Diseases (AASLD) guidelines on portal hypertensive bleeding.

59. European Association for the Study of the Liver. Electronic address eee, European Association for the Study of the L. EASL clinical practice guidelines for the management of patients with decompensated cirrhosis. J Hepatol. 2018;69:406-60. https://doi.org/10. 1016/j.jhep.2018.03.024. European Association for the Study of the Liver (EASL) guidelines on decompensated cirrhosis.

60. Thalheimer U, Bosch J, Burroughs AK. How to prevent varices from bleeding: shades of grey - the case for nonselective beta blockers. Gastroenterology. 2007;133(6):2029-36. https://doi.org/ 10.1053/j.gastro.2007.10.028.

61. Villanueva C, Aracil C, Colomo A, Balanzo J. Nonselective betablockers and hepatic venous pressure gradient monitoring: what lies behind nonresponse. Gastroenterology. 2008;134(5):1626-7; author reply 7-8. https://doi.org/10.1053/j.gastro.2008.03.065.

62. Reiberger T, Ferlitsch A, Payer BA, Mandorfer M, Heinisch BB, Hayden $\mathrm{H}$, et al. Non-selective betablocker therapy decreases intestinal permeability and serum levels of LBP and IL-6 in patients with 
cirrhosis. J Hepatol. 2013;58(5):911-21. https://doi.org/10.1016/j. jhep.2012.12.011.

63. Senzolo M, Cholongitas E, Burra P, Leandro G, Thalheimer U, Patch D, et al. Beta-blockers protect against spontaneous bacterial peritonitis in cirrhotic patients: a meta-analysis. Liver Int: Off J Int Assoc Stud Liver. 2009;29(8):1189-93. https://doi.org/10.1111/j. 1478-3231.2009.02038.x.

64. Bang UC, Benfield T, Hyldstrup L, Jensen JB, Bendtsen F. Effect of propranolol on survival in patients with decompensated cirrhosis: a nationwide study based Danish patient registers. Liver Int: Off J Int Assoc Stud Liver. 2016;36:1304-12. https://doi.org/10.1111/liv. 13119.

65. Mookerjee RP, Pavesi M, Thomsen KL, Mehta G, Macnaughtan J, Bendtsen F, et al. Treatment with non-selective beta blockers is associated with reduced severity of systemic inflammation and improved survival of patients with acute-on-chronic liver failure. J Hepatol. 2016;64(3):574-82. https://doi.org/10.1016/j.jhep.2015. 10.018 .

66. Albillos A, Zamora J, Martinez J, Arroyo D, Ahmad I, De-la-Pena $\mathrm{J}$, et al. Stratifying risk in the prevention of recurrent variceal hemorrhage: results of an individual patient meta-analysis. Hepatology. 2017;66(4):1219-31. https://doi.org/10.1002/hep.29267 Metaanalyses highlighting that NSBB are the key component of combination treatment.

67. Pfisterer N, Dexheimer C, Fuchs EM, Bucsics T, Schwabl P, Mandorfer M, et al. Betablockers do not increase efficacy of band ligation in primary prophylaxis but they improve survival in secondary prophylaxis of variceal bleeding. Aliment Pharmacol Ther. 2018;47(7):966-79. https://doi.org/10.1111/apt.14485 Austrian real-life study highlighting the importance of NSBB treatment in secondary prophylaxis.

68. Casu S, Berzigotti A, Abraldes JG, Baringo MA, Rocabert L, Hernandez-Gea V, et al. A prospective observational study on tolerance and satisfaction to hepatic haemodynamic procedures. Liver Int: Off J Int Assoc Stud Liver. 2015;35(3):695-703. https://doi. org/10.1111/liv.12522.

69. Ferlitsch A, Bota S, Paternostro R, Reiberger T, Mandorfer M, Heinisch B, et al. Evaluation of a new balloon occlusion catheter specifically designed for measurement of hepatic venous pressure gradient. Liver Int: Off J Int Assoc Stud Liver. 2015;35(9):211520. https://doi.org/10.1111/liv.12783.

$70 . \bullet$ Berzigotti A. Non-invasive evaluation of portal hypertension using ultrasound elastography. J Hepatol. 2017;67(2):399-411. https:// doi.org/10.1016/j.jhep.2017.02.003 Detailed review article on non-invasive methods for diagnosing/monitoring portal hypertension.

71. Piecha F, Mandorfer M, Peccerella T, Ozga AK, Poth T, Vonbank A, et al. Pharmacological decrease of liver stiffness is pressurerelated and predicts long-term clinical outcome. Am J Physiol Gastrointest Liver Physiol. 2018;315(4):G484-G94. https://doi. org/10.1152/ajpgi.00392.2017.

72. Mandorfer M, Reiberger T, Peck-Radosavljevic M. Monitoring the evolution of portal hypertension after sustained virologic response. Gastroenterology. 2018;154(5):1550-1. https://doi.org/10.1053/j. gastro.2017.08.078.

73. Reiberger T, Ferlitsch A, Payer BA, Pinter M, Homoncik M, PeckRadosavljevic M, et al. Non-selective beta-blockers improve the correlation of liver stiffness and portal pressure in advanced cirrhosis. J Gastroenterol. 2011;47:561-8. https://doi.org/10.1007/ s00535-011-0517-4.

74. Jansen C, Moller P, Meyer C, Kolbe CC, Bogs C, Pohlmann A, et al. Increase in liver stiffness after transjugular intrahepatic portosystemic shunt is associated with inflammation and predicts mortality. Hepatology. 2018;67(4):1472-84. https://doi.org/10. 1002/hep.29612.

75. Colecchia A, Montrone L, Scaioli E, Bacchi-Reggiani ML, Colli A, Casazza G, et al. Measurement of spleen stiffness to evaluate portal hypertension and the presence of esophageal varices in patients with HCV-related cirrhosis. Gastroenterology. 2012;143(3):64654. https://doi.org/10.1053/j.gastro.2012.05.035.

76. Takuma Y, Nouso K, Morimoto Y, Tomokuni J, Sahara A, Takabatake H, et al. Portal hypertension in patients with liver cirrhosis: diagnostic accuracy of spleen stiffness. Radiology. 2016;279(2):609-19. https://doi.org/10.1148/radiol.2015150690.

77. Piecha F, Peccerella T, Bruckner T, Seitz HK, Rausch V, Mueller S. Arterial pressure suffices to increase liver stiffness. Am J Physiol Gastrointest Liver Physiol. 2016;311(5):G945-G53. https://doi. org/10.1152/ajpgi.00399.2015.

78. Procopet B, Berzigotti A, Abraldes JG, Turon F, Hernandez-Gea V, Garcia-Pagan JC, et al. Real-time shear-wave elastography: applicability, reliability and accuracy for clinically significant portal hypertension. J Hepatol. 2015;62(5):1068-75. https://doi.org/10. 1016/j.jhep.2014.12.007.

79. Zhu Y, Ding H, Fu T, Peng S, Chen S, Luo J, et al. Portal hypertension in hepatitis B related cirrhosis: diagnostic accuracy of liver and spleen stiffness by two-dimensional shear-wave elastography. Hepatol Res. 2018. https://doi.org/10.1111/hepr.13306.

80. Choi SY, Jeong WK, Kim Y, Kim J, Kim TY, Sohn JH. Shear-wave elastography: a noninvasive tool for monitoring changing hepatic venous pressure gradients in patients with cirrhosis. Radiology. 2014;273(3):917-26. https://doi.org/10.1148/radiol.14140008.

81.• Kim HY, So YH, Kim W, Ahn DW, Jung YJ, Woo H, et al. Noninvasive response prediction in prophylactic carvedilol therapy for cirrhotic patients with esophageal varices. J Hepatol. 2018. https:// doi.org/10.1016/j.jhep.2018.10.018 Study on the use of elastography for assessing HVPG-response to NSBB.

82. Palaniyappan N, Cox E, Bradley C, Scott R, Austin A, O'Neill R, et al. Non-invasive assessment of portal hypertension using quantitative magnetic resonance imaging. J Hepatol. 2016;65(6):11319. https://doi.org/10.1016/j.jhep.2016.07.021 Study on the use of MRI for the assessment of portal hypertension.

83. Trebicka J, von Heydebrand M, Lehmann J, Tofteng F, Busk T, Jensen HL, et al. Assessment of response to beta-blockers by expression of betaArr2 and RhoA/ROCK2 in antrum mucosa in cirrhotic patients. J Hepatol. 2016;64(6):1265-73. https://doi.org/10. 1016/j.jhep.2016.01.022.

84. Reverter E, Lozano JJ, Alonso C, Berzigotti A, Seijo S, Turon F, et al. Metabolomics discloses potential biomarkers to predict the acute HVPG response to propranolol in patients with cirrhosis. Liver Int: Off J Int Assoc Stud Liver. 2019. https://doi.org/10. 1111/liv.14042 Study on the use of metabolomics for assessing HVPG-response to NSBB.

Publisher's Note Springer Nature remains neutral with regard to jurisdictional claims in published maps and institutional affiliations. 